Галіна Тварановіч

Беласток

\title{
Літаратуразнаўчыя пошукі Алеся Яскевіча
}

Праніклівы, глыбокі даследчык літаратуры прафесар, доктар філалагічных навук Алесь Яскевіч прыйшоў у сваю прафесію на новым этапе развіцця беларускай крытыкі і літаратуразнаўства - у другой палове 50-х гадоў. Як вядома, глыбокія змены ў грамадска-палітычным жыцці краіны падчас так званай "хрушчоўскай адлігі" знайшлі яскравае выяўленне ва ўсіх сферах гуманістыкі. Зразумела, не аказалася выключэннем і навука аб літаратуры, што выявілася як у значным пашырэнні шэрагаў крытычна-літаратуразнаўчага цэха, так адпаведна і кола пытанняў, праблем, якія адразу трапілі у поле зроку Алеся Адамовіча, Івана Навуменкі, Уладзіміра Калесніка, Алега Лойкі, Ніла Гілевіча, Анатоля Клышкі, Віктара Каваленкі, Міхася Лазарука, Анатоля Сабалеўскага, Юліі Канэ, Дзмітрыя Бугаёва, Міхася Стральцова, Адама Мальдзіса і шэрагу іншых маладых даследчыкаў. Найперш гэта яны разам з ужо вядомымі на той час крытыкамі Уладзімірам Юрэвічам, Рыгорам Бярозкіным, Юльянам Пшырковым, Навумам Перкіным, Васілём Івашыным, Фёдарам Куляшовым, Сцяпанам Александровічам, Рыгорам Шкрабам, Марынай Барсток, якія нібы набылі "новае дыханне", вызначалі воблік, надавалі адпаведны рытм беларускім літаратуразнаўству і крытыцы другой паловы XX-пачатку XXI стагоддзяў. Міхась Мушынскі ̈̈ апошняй па часе акадэмічнай гісторыі беларускай літаратуры мінулага стагоддзя, ініцыятарамі і аўтарамі якой, дарэчы, з'яўляюцца у значнай ступені названыя вышэй асобы, дакладна вызначыў мэты, якія мусілі быць вырашаны тагачасным літаратуразнаўча-крытычным цэхам: 
Першачарговай задачай прадстаўнікой новай генерацыі крытыкаў было выкараненне вульгарнай сацыялогіі і выпрацоўка новых метадалагічных падыходаў, пры якіх улічвалася б складаная сувязь паміж літаратурай і жыццём, у прыватнасці, эстэтычная прырода літаратуры як праявы духойнай дзейнасці чалавека. Адчувалася вострая неабходнасць і ў адраджэнні прынцыпа аб'ектыўнай ацэнкі літаратурна-мастацкіх з'яў, ва ўсталяванні атмасферы высокай патрабавальнасці да друкаванага і вуснага слова. Неабходна было як хутчэй давесці грамадскасці, што літаратурная крытыка не ёсць паслухмяны праваднік ідэалагічных установак ці выканаўца патрабаванняў афіцыёзу, а паўнапраўная частка літаратуры. I роля крытычнага слова $\ddot{y}$ літаратурным працэсе надзвычай вялікая, а функцыі - разнастайныя ${ }^{1}$.

Алесь Яскевіч належыць да так званага філалагічнага пакалення, "шасцідзесятнікай”, “дзяцей вайны". Па заканчэнні вясковых школ яны працягвалі адукацыю пераважна на філалагічных факультэтах педагагічных інстытутай, Беларускага дзяржаўнага ўніверсітэта або на факультэце журналістыкі, як А. Яскевіч. Народжаны у 1934 годзе у сялянскай сям'і на Магілёушшчыне, ён рана, як і многія яго аднагодкі, застаўся без бацькі, які загінуй на фронце. Гэта менавіта таленавітае, шматгалосае пакаленне "дзяцей вайны", што ўваходзіла у сталае жыццё у 50-я гады, відавочна, на той час не задумваючыся аб сваім высокім прадвызначэнні, мусіла галоўным чынам выканаць ганаровую адраджэнчую місію, ускладзеную на яго самой трагічнай беларускай гісторыяй. Уласна, здзейсніцца як у сваім творчым лёсе, так і надрабіць тое, што не паспелі здзейсніць папярэднікі - шматлікія ахвяры сталінскіх рэпрэсій ${ }^{2}$ і спусташальнай Другой сусветнай вайны. Хоць, зразумела, што з адыходам кожнага чалавека назаўсёды згасаюць і адзіны непаўторныя свет, і ўнікальныя творчыя магчымасці.

3 крытычнымі артыкуламі і рэцэнзіямі Алесь Яскевіч пачаў выступаць адразу пасля заканчэння ўніверсітэта ў 1958 годзе. Вельмі важным для станаўлення яго творчай асабовасці быў перыяд навучання (1961-1964) у аспірантуры Інстытута літаратуры імя Янкі Купалы Акадэміі навук Беларусі. Варта згадаць, што менавіта Інстытут літаратуры ў другой палове XX стагоддзя вызначаў беларускі літаратуразнаўчы "клімат". У розны час тут працавалі і працуюць, апрача ўспомненых ужо Алеся Адамовіча, Івана Навуменкі, Віктара

\footnotetext{
1 Крытыка і літаратуразнаўства (М. Мушынскі), (у:) Гісторыя беларускай літаратуры XX стагоддзя. У 4-х т., Мінск 2001, т. 3, с. 173.

2 Гл.: Расстраляная літаратура. Творы беларускіх пісьменнікай, загубленых карнымі органамі бальшавічкай улады, Мінск 2008, с. 694.
} 
Каваленкі, Адама Мальдзіса - Павел Дзюбайла, Вячаслаў Зайцаў, Міхась Мушынскі, Васіль Жураўлёў, Серафім Андраюк, Варлен Бечык, Мікола Арочка, Міхась Ярош, Генадзь Кісялёў, Эсфір Гурэвіч, Валянціна Гапава, Уладзімір Мархель, Сцяпан Лаўшук, Міхась Тычына, Ала Кабаковіч, Вячаслаў Жыбуль, Тамара Чабан і іншыя даследчыкі. Сектару тэоры літаратуры, у які А. Яскевіч быў прыняты на працу спачатку малодшым навуковым супрацоўнікам, ён заставаўся верным доўгія плённыя гады, літаральна да нядаўняга выхаду на пенсію. Абароненая ім у 1965 годзе кандыдацкая дысертацыя на тэму "Праблемы стылю беларускай прозы ранняга перыяду" засведчыла, што у беларускае літаратуразнаўства прыйшой даследчык з выразным навукова-творчым патэнцыялам, якому пад сілу вырашаць разнастайныя аспекты гісторыі і тэоры літаратуры.

Першую кнігу А. Яскевіча "Карані маладога дрэва" склалі артыкулы, што пісаліся ў розныя гады і з рознай нагоды. У анатацыі да яе між іншага адзначалася: Магчьма, што-нішто крытыкам выказана суб'ектыўна. Але галоўнае, што аб'яднойвае іх (артыкулы - Г.Т.), шчыры клопат аўтара пра тое, каб маладое дрэва беларускай літаратуры, узрошчанае на ўрадлівай глебе фальклорных традыцый (выдзелена - Г.Т.), не спыняла свой рост і абнаўлялася з кожнай новай парой, даверыўшыся жыватворным вятрам нашага векуз. Ва ўнісон гэтаму па-свойму нібы нават катэгарычнаму сцвярджэнню кніга адкрывалася артыкулам "Пачатак" (1963), у якім малады літаратуразнавец кампетэнтна і вельмі зацікаўлена абгрунтойваў на матэрыяле ранняй беларускай прозы рашаючую ролю вуснай народнай творчасці ў станаўленні новай літаратуры. Тое, што за некалькі дзесяцігоддзяў з-за гвалтоўнай перарванасці багатых традыцый адраджэнскага "залатога веку" беларуская літаратура у Х XIX стагоддзі мусіла адолець больш як двухсотгадовы прамежак, пройдзены суседнімі літаратурамі у больш-менш "нармальных" умовах, слушна бачылася аўтару вялікім подзвігам. I менавіта фальклор стаў выказнікам духойнага жыция $i$ таленавітасиі народа, яго эстэтычных запатрабаванняў (4). Даследчык падкрэсліваў, што паперад аднаўлення магчымасцей друкаванай літаратуры ў беларусай ужо існавала празаічная традыцыя, выяўленая ў народных апавяданнях або казках, а гэта давала падставы для наступных глыбокіх высной:

3 А. Яскевіч, Карані маладога дрэва, Мінск 1967, с. 2. Далей пры спасылцы на гэта выданне $\breve{y}$ дужках падаецца старонка. 
I што асабліва цікава, у далейшым пры з'яўленні прафесійнай літаратуры, пэўны час не было асаблівага разрыву паміж прозаю ў яе фальклорных формах і літаратурай пісьмовай. Тут мы назіраем вельмі спецыфічную ў нашых нацыянальных умовах з'яву - надзвычай поўнае засваенне фальклора літаратураю, шчодрае наследаванне яго стылістыкі і паэтыкі. Гэта зусім не азначала, вядома, што фальклор цалкам "паглынаўся" пісьмовай літаратурай і пераставаў бытаваць. Мы толькі хочам падкрэсліць, што ў беларусаў адбылося больш поўнае і арганічнае засваенне моўных і мастацкіх багаццяў, накопленых фальклорам, чым звычайная частковая трансфармацыя вуснай паэтычнай творчасці, народнага слова, што было характэрна для літаратур са значнай пісьмовай традыцыяй (6).

Апярэджваючы пытанне адносна таго, навошта было беларускай літаратуры карыстацца фальклорнай няразвітай, хоць і самабытнай, традыцыяй, калі можна было скарыстаць вопыт літаратур суседніх народаў, якія дасягнулі да гэтага часу класічных вышынь, А. Яскевіч выказвай канцэптульна важкую думку:

У нацыянальным мастацтве вельмі важна ісці шляхам, які зададзены развіццём папярэдняй мастацкай думкі. А ўлічваючы ўсю цяжкасць і працягласць выпрацоўкі стылёвай традыцыі, было мэтазгодна працягваць і развіваць тое, што узжо назапасіла народная практыка, калі мы хацелі, каб атрымалася што-небудзь самабытнае, нацыянальнае. I наогул, каб што-небудзь атрымалася (...) Перайманне народнай традыцыі на першай ступені было адзіна правільным, бо толькі так можна было спазнаць і адлюстраваць рэчаіснасць, як нацыянальную $(23,24)$.

Пры тым даследчык падкрэсліваў, напрыклад, што простая структура народнага апавядання або казкі ствараецца плынню трапных народных выразаў, якія працуюць на паказ толькі асноўнага агульнага дзеяння. У той час як у прафесійным апавяданні задзейнічаны зусім іншы кампазіцыйны лад: не фразавае, а - вобразнае счапленне, абумоўленае мастацкімі дэталямі і карцінамі, на змену ж знешняй, лексічнай логіцы прыходзіць унутраная, вобразная логіка. Так што, здавалася б, самьл мірны пераход фальклору ў літаратуру павінен быў уяўляць сабой складань дыляектычны скачок, у выніку якога проза павінна набыць новьля якасиі, дасягнуць узройню вьлскай творчай культурь (33). Зразумела, згадваў А. Яскевіч удзячна Максіма Багдановіча, які напачатку XX стагоддзя ў артыкуле “Забыты шлях" акрэсліў магістральныя накірункі развіцця беларускага прыгожага пісьменства, аддаючы належнае менавіта свайму, роднаму і заклікаючы да засваення вопыту сусветнай літаратуры. 
Наступны свой артыкул "Пошукі стылю" (1963) А. Яскевіч распачынаў якраз са звароту да тэарэтычнага і творчага плёну М. Багдановіча, падкрэсліваючы, што роля напружанай стылёвай практыкі аўтара "Вянка" ўзрастае з кожным новым пакаленнем. I гэта найперш школа майстэрства слова наймаладога беларускага класіка была актуальнай у сярэдзіне 20-х гадой для творчых пошукай большасці сяброй "Узвышша", дзейнасць якога, на жаль, доўгі час ацэньвалася далёка не адэкватна яе зместу і значэнню для беларускай літаратуры. А. Яскевіч, прадстаўнік новай генерацыі крытыкаў, выказваўся прама і канкрэтна:

Вялікая, неаспрэчная роля літаратурна-мастацкага згуртавання "Узвышша" у развіцці нашай літаратуры павінна быць прызнана у нашай навуцы, павінна быць вернута гэтаму згуртаванню яго заслужанае добрае імя і глыбока вывучаны яго тэарэтычныя і творчыя здабыткі. Гэтага, апрача ўсяго, патрабуе наша сучасная практыка, якая вырашае многія з тых творчых праблем, што ўпершыню, па сутнасці, былі так сур'ёзна пастаўлены ўзвышаўцамі (45).

Як вядома, добрае імя мусіла вяртацца шэрагу “ўзвышаўцай" і многім з іх ужо пасмяротна ды разам з іхняй рэпрасаванай творчасцю. У сваім артыкуле А. Яскевіч робіць вельмі кампетэнтную спробу франтальнага аналізу тагачаснай літаратурнай сітуацы ў сацыяльна-гістарычным кантэксце. Пры гэтым своеасаблівым магнітацэнтрам артыкула аказваецца творчая пазіцыя, стылявыя пошукі "ўзвышаўцаў". Аддаецца належнае дзейнасці вялікага майстра лірычнага слова Уладзіміра Дубоўкі і Адама Бабарэкі - вылатнага крытыла, які меў высокую мастачкую $i$ літаратуразнаўчую падрыхтоўку, валодаў тонкім крытычным талентам (46) і жыццё якога заўчасна перарвалася ў адной з гулагаўскіх бальніц у 1938 годзе. Відавочна, што творчасць "узвышаўцаў" вытрымала праверку часам і невыпадкова, што артыкул "Пошукі стылю" заканчваўся высноваю, прасякнутай шчырым клопатам аб стане роднай літаратуры:

За дрэнны стыль, за слабую мастацкасць даруе яшчэ сучаснік, сарамліва хаваючы вочы, прамаўчыць сябра па пяру і крытык, але тым больш бязлітасна адпомсціць за гэта час. Мы сведкі таго, як проста на вачах паміраюць творы не высокай культуры, якія яшчэ дзесяць год былі папулярнымі і нават грымелі, і як нашчадкі беражліва прымаюць тых, хто шліфаваў і выношваў кожнае слова, пісаў па-высокамастацку, складана, не звяртаючы ўвагі, што прымітыўныя людзі часам і не прымалі яго.

Час патрабуе, час натхняе (61). 
Аб тым, што малады даследчык ішой па цаліку, смела браўся за вырашэнне надзвычай складаных пытанняў станаўлення нацыянальнага класічнага стылю, сведчыць і артыкул "Самы лёгкі ці самы цяжкі?" (1965), у якім была зроблена спроба асэнсавання жанру сучаснай беларускай лірычнай прозы. I трэба падкрэсліць, што маладому аўтару ўдалося выказаць канцэптуальна важныя меркаванні як адносна генезісу, так і працэсу станаўлення, далейшага развіцця гэтага складанага жанру канкрэтнымі пісьменнікамі. Улоўлены быў ім таксама сутнасны момант, пафасная спецыфіка, што, відаць, у значнай ступені абумоўлівае ӱзнікненне лірычнай прозы:

Гаворку пра спецыфіку лірычнай прозы трэба, мабыць, пачынаць з праблемы чалавечага ідэалу. Лірычная проза у больш за ўсё набліжана да ідэалу, той праграмы, мэты дасканаласці, да якой павінен дайсці род чалавечы. Свет лірычнай прозы - ідэальны, шчаслівы, благаславенны стан чалавека, і вельмі трэба берагчы гэтае права і гэтую здольнасць лірычнай прозы - гаварыць пра гэта і гэтак, менавіта тымі сродкамі, якія падуладны ёй (83).

Варта сказаць, што дакладнасць назіранняў крытыка адносна гэтай празаічнай дзялянкі пацверджана часам, аб чым сведчыць той факт, што ні адзін сур'ёзны разгляд беларускай лірычнай прозы і ў XXI стагоддзі не абыходзіцца без спасылак на "Карані маладога дрэва".

Востра паўстала ў перыяд "адлігі" праблема традыцый і наватарства. Літаратура мусіла як мага хутчэй пераадолець каноны, навязаныя ёй нарматыўнай, з'ідэалагізаванай крытыкай, зрошчанай з уладнымі структурамі. Трэба было, як ужо адзначалася, рэабілітаваць традыцыі, напрацаваныя ахвярнымі падзвіжнікамі беларускага слова. У артыкулах А. Яскевіча "Традыцыйнае і наватарскае" (1962) і "Яшчэ раз аб наватарстве" (1967) разглядаліся разнастайныя аспекты гэтай важнай праблемы. Між іншым выказвалася думка:

У апошні час навука ўсё больш прыходзіць да вываду, што вялікія, найбольш складаныя з'явы можна пазнаць метадам пабудовы мадэлі, г. зн. шляхам узнаўлення аб'екта, які даследуецца, у больш спрошчанай, прынцыповай схеме - структуры.

I аказалася, што мастацтва з моманту свайго зараджэння якраз і карыстаецца гэтым прынцыпам, мастацкі твор - гэта і ёсць своеасаблівая мадэль жыцця, з дапамогай якой пісьменнік толькі і мае магчымасць падступіцца, даследаваць гэтую рухомую, непадатлівую, бяскрайнюю стыхію - рэчаіснасць (180). 
Зараз відавочна, што змест "Каранёў маладога дрэва" яскрава прадстаўляў шырокі дыяпазон даследчыцкіх інтарэсай выдатнага літаратуразнаўца, якога крыху пазней, адзначаючы здольнасць ставіць пытанні і знаходзіць адказы на ix, калегі жартаўліва-шаноўна назавуць "генератарам ідэй". Серафім Андраюк, таксама адзін з найяркіх прадстаўнікой беларускага літаратуразнаўства, распавядаючы $\ddot{y}$ сваіх успамінах пра творчую атмасферу $\ddot{y}$ акадэмічным Інстытуце літаратуры, напіша: Натхнёны вынаходиа ў літаратуры новых духойньих і эстэтычных ідэй Алесь Яскевіч4.

Наступная кніга А. Яскевіча "Грані майстэрства" галоўным чынам прысвечана разгляду індывідуальнасці пісьменніка, псіхалогіі творчасці, што азначала найперш спробу вызначэння таемнага таемных прыгожага пісьменства: Што ж яно такое, гэтае натхненне? Таямнічая сіла, якая невядома адкуль бярэича і невядома куды знікае? Ці магутны творчь імпульс, які уัзнікае ў душы мастака $i$ так иудадзейна актывізуе творчы прачэс? Тады якая яго прырода? 55 Мусіць быць устаноўлена сувязь паміж аўтарскім "я" і героямі твораў пісьменніка, вывучана трансфармацыя пісьменніцкага вопыту і жыццёвага матэрыялу ў творчасць, што падводзіць да працэсу стварэння мастацка-эстэтычнай рэчаіснасці.

Ужо ў "Гранях майстэрства" напоўніцу выяўляецца такая ўласцівасць даследчай манеры А. Яскевіча, як разамкнутасць аналітычнай думкі на аснове свайго, беларускага, вопыту ў славянскі, еўрапейскі кантэкст, плённае ўспрыняцце і ўвядзенне у у нацыянальны ўжытак новых фактай. У выніку адбываецца ўдакладненне істотных момантаў развіцця ўласнай літаратуры, абумоўленага агульнамастацкімі законамі. Звяртаецца аўтар "Граняў майстэрства" і да праблемы стылю, але ӱжо не як гісторык літаратуры, а з пазіцы менавіта тэарэтыка. У раздзеле "Нараджэнне стылю" ён найперш акцэнтуецца на naчатку сэнсавых стыхій, апелюючы між іншым да вопыту Льва Талстога, Паўла Антакольскага, Гётэ, Гегеля, Моцарта... Тут аказваецца навідавоку пэўная інтэрдысцыплінарнасць гэтага даследавання, што надалей набудзе у большасці прац А. Яскевіча сталы характар. Трэба пры тым зазначыць, што развагі над вызначэннем стылю вядуцца ў нязменнай прысутнасці беларускай літаратуры:

\footnotetext{
4 С. Андраюк, Новыля старонкі. Успаміны, «Тэрмапілы», 2014, № 18, с. 13.

5 А. Яскевіч, Грані майстэрства, Мінск 1974, с. 6. Далей пры спасылцы на гэта

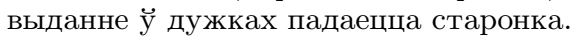


Стыль у мастацкім творы выяўляе сябе $\breve{y}$ якасці жыватворчага, у вышэйшай ступені актыўнага пачатку. 3 ім звязана цэласнасць рэчы, прарыў праз хаос да адзінства.

У рамане Янкі Брыля "Птушкі і гнёзды" столькі сэнсавых стыхій, столькі жыццёвых, разнародных па характару пластой: эпізоды партызанскага жыцця, пакутлівая адысея Руневіча ў фашысцкім палоне і ўцёкі з яго, гады маленства, пададзеныя праз успамін, і іншае, але уусё аб'яднаў, спалучыў сваёй магутнай воляй энергічны аўтарскі стыль (43).

У наступным падраздзеле "Саюз слова і вобраза" А. Яскевіч звяртае ўвагу на тое, што літаратуразнаўчая стылістыка павінна была б шырока карыстацца і мойным матэрыялам, бо ў творах слоўнага мастацтва няма іншай рэальнасці апрача слова і ўсё вобразнае багачче вылуัляециа праз мову і у рэаліях мовы (49). Таму важным крокам бачыцца даследчыку выкарыстанне літаратуразнаўствам лінгвістычнай стылістыкі, што паслужыла б узбагачэнню і апошняй, бо: Каб зразумець мойны стыль, неабходна звярнуциа да таго ж самага, што $i$ ў літаратуразнаўстве - да руху мойнага зместу $і$ формьи уั лексіиьл, сінтаксісе, а затыл у фанетыцы, марфалогіi (51). Менавіта вывучэнне спецыфікі беларускай мовы, яе стылістычнай сістэмы, своеасаблівасці шляхоў яе развіцця дазваляе зрабіць больш пэўныя высновы адносна своеасаблівасці нацыянальнага стылю. На думку А. Яскевіча, проста неабходнай з'яўляецца і практыка супастаўлення стылістык розных мастацтваў, бо Супастайленне вобразнай сістэмы слойнага мастачтва з вобразнымі структурамі музыкі, жывапісу, архітэктуры дазваляе поглядам збоку, метадам параўнання зразумець многае з таго, што не адкрьвваециа знутры (62). I, натуральна, што далей А. Яскевіч звяртаецца да ўзаемаадносін стылю і жанру, спрабуе прасачыць сувязь паміж жанравай формай і стылёвымі формаўтваральнымі працэсамі. Амаль адразу ён сведчыць: Жанр, па нашых меркаваннях, $i$ ўяуляе сабой закончань, завершаны стылль, “зачвярдзельл" на нейкіх вузлавых $i$ агульных структурных момантах формы, прынцыпь якой кананізуючча і становячиа літаратурнай традыцылй (69). Звяртае даследчык увагу на пачуццё жанравай традыцыі, тэматычную абумоўленасць у выбары жанру, ролю пры тым мойнага матэрыялу, функцыянальных стыляў, якія адпавядаюць характару тэмы.

У чарговай сваёй кнізе "У свеце мастацкага твора" А. Яскевіч на матэрыяле творчасці Івана Мележа, Янкі Брыля, Івана Шамякіна, Васіля Быкава, Івана Пташнікава, Міхася Стральцова, Барыса Сачанкі і іншых пісьменнікаў імкнуўся пранікнуць у нетры вобразнай структуры твора, каб "падгледзець" функцыянаванне механізмай і звенняў 
гэтай структуры ў працэсе яе вобразнага жыцця, прасачыць складаны працэс тыпізацыі ў мастацкім творы. Пры тым А. Яскевіч сыходзіӱ 3 меркавання:

А самы галоўны напрамак даследавання, дзе, як нам думаецца, даследчыку найбольш пашчасціць патрапіць на сляды ўтварэння мастацкіх законаў, ляжыць ва ўсім вядомай сферы ўзаемаадносін мастацтва (кожнага мастака ўпаасобку) з жыццём. Прасачыць "складванне" мастацкага твора ад задумы да здзяйснення, гэты патаемны працэс трансфармацыі жыццёвага матэрыялу ў матэрыял мастацкай творчасці - вось, думаецца, дзе даюцца даследчыку найбольшыя магчымасці паназіраць твор, як кажуць, у адкрытым стане ${ }^{6}$

Актыўна звяртаючыся да класічнага досведу і сыходзячы 3 назапашанага вопыту, даследчык звяртаў увагу на тое, што мастацкая праўда і праўда рэчаіснасці нібы разведзены па розных берагах ракі, таму значная ступень умоўнасці дасягаецца менавіта ў выніку пераадолення складанай паласы пераўтварэнняў, якая ляжыць паміж жыццём і яго ўзнаўленнем у мастацкім творы. Даследчая задума паступова рэалізуецца у раздзелах "Круг новага набліжэння", "Прырода", "Псіхалогія. Крыху эксперыментальных дадзеных", "Пластыка. Кампазіцыя", "Характар" і лагічна завяршаецца, можна сказаць, ужо класічнай высновай, якая акрэслівае асноватворныя для айчыннага творцы дамінанты:

Пры распрацоўцы і пошуках новай формы ёсць таксама ўніверсальны прынцып: глыбокае ўсведамленне і адчуванне талентамі ці мастацкай школай, якія стаяць у авангардзе літаратурнага працэсу сваёй нацыянальнай літаратуры, самой літаратурнай прыроды, і у першую чаргу тых багатых стыхій, якія у сваім шчаслівым спалучэнні ўтварылі яе геній. Тады талент, які ідзе шляхам самабытнага пошуку, не саб'ецца на нейкую адну яе вузкую грань, а будзе жыць адчуваннем, што сапраўдныя адкрыцці ляжаць на скрыжаванні ўсіх яе "прырод" і што толькі там можна напаткаць новае памнажэнне вобразных магчымасцей літаратуры ${ }^{7}$.

Яшчэ напрыканцы шасцідзесятых гадоў А. Яскевіч звярнуўся да праблемы, грунтойная распрацойка якой, нягледзячы на яе заўсёдную актуальнасць, неяк усё заставалася на перыферыі беларускага літаратуразнаўства. У прыватнасці, артыкул “Цяжкое мастацтва перакладу" сведчыў аб усталяваных ужо поглядах і вырашэннях яшчэ

\footnotetext{
6 А. Яскевіч, У свеце мастацкага твора, Мінск 1977, с. 8.

7 Тамсама, с. 206.
} 
маладога, але ўжо і вопытнага, даследчыка ў галіне мастацкага перакладу. На завяршэнне свайго артыкула, ён канстатаваў:

Нас не можа не засмучаць тое, што ў сябе, у рэспубліцы, мы сёння не можам назваць крытыкаў ці літаратуразнаўцаў, якія сур'ёзна спецыялізаваліся б на перакладах. А не трэба ж забываць, што сённяшні незадавальняючы стан многіх перакладаў, якія мы паспелі разгледзець, залежыць не толькі ад перакладчыкай, але ў значнай ступені абумойлены ўзроўнем перакладчыцкай тэорыі, нераспрацаванасцю параўнальнай лексікі, адсутнасцю патрабавальнасці і сур'ёзнага рэцэнзавання перакладной літаратурнай прадукцыі ${ }^{8}$.

I вось плён шматгадовых назіранняў вучонага на гэтай дзялянцы даносіла кніга А. Яскевіча "Выхад за круг", што распачыналася якраз трыма глыбокімі перакладазнаўчымі артыкуламі. Адразу было сцверджана, што дзеля паспяховага перастварэння мастацкага твора з адной моўнай стыхіі на другую, патрабуецца выхад за круг блізкіх, звылльх рашэнняў. Уздымалася найперш праблема перакладу з блізкамоўных літаратур. Здавалася б, што тут паспяховая рэалізацыя перакладчай практыкі забяспечана самой моўнай роднасцю. Аднак, падкрэсліваў даследчык, у плане моўных адрозненняў можа сустрэииа зусім асобны выпадак перакладчьикіх ияжкасцей, калі бадай што ўвесь элемент нащьянальнай своеасаблівасиі, што якраз і павінна ўяўлячь галоўную иікавасиь для нацьянальнага мьллення, застаециа за межамі перакладу9. I як ні парадаксальна, а найчасцей такія выпадкі маюць месца пры перастварэнні якраз не з няроднасных, далёкіх моў, а менавіта - з блізкароднасных, пры ўмове, што яны з'яўляюииа мовамі розных шляхоў, иі, як ияпер кажуць, розных этнакультурньх традыциьй утварэння (5).

Аддаленасць моў ужо адразу выключае літаральнасць перакладу, змушае да перастварэння ўсёй складанай сістэмай новай мовы. У той час як гіпноз максімальнага падабенства амаль што скрадвае адрозненні (5), што знайшло асабліва яскравае праяўленне ў перакладах ранняй беларускай класікі на рускую мову. Даследчык упэўнены, што, каб зразумець асаблівасці моватворчасці Купалы, Коласа, Багдановіча і іншых, перакладчык мусіць глыбока ўвайсці ў моўную і нацыянальную стыхію, пастарацца зразумець жыватворныя вытокі традыцыі. Трэба

\footnotetext{
8 А. Яскевіч, Грані майстэрства, с. 101.

9 А. Яскевіч, Выхад за круг. Літаратуразнаўчыля артылулы, Мінск 1985, с. 4-5. Далей пры спасылцы на гэта выданне ў дужках падаецца старонка.
} 
ўлічваць, што на пачатку мінулага стагоддзя беларуская літаратурная мова толькі што выходзіла з стану мовы вуснай, найбольш поўна і арганічна яе засвойваючы. У такім шляху фарміравання, удакладняе А. Яскевіч, былі і станоўчыя, і негатыўныя моманты. Mове, nepampbманай у вусным стане, якая не ведала зусім іншароднага кніжнага элемента, што па-свойму ўзбуджаў бы этнічную кроў $i$ такім чынам аблягчаў фарміраванне абстрактных $і$ пераносньх значэнняу у слове, з асаблівай ияжкасию мусіла давачиа развічиё менавіта (...) адиягненых кніжных стыляу (13). Асновай жа для рана сфарміраваных літаратурных моў, як, напрыклад, для рускай, служыла кніжная традыцыя, а адаптацыя жывых плыняў вуснай народнай гаворкі адбывалася пазней. Для перадачь эпічнай рэчыўнасиі беларускага слова $i$ верша, - адзначае А. Яскевіч, - хачелася б крыху абчяжарыць, затрымачь, зменшыць гэтыл лірычны гладкапіс иі хочь бы выразней пазначыць иэзуры і рытмічныл паўзы. У перайначаным такім чынам рытмарадзе, глядзі, і слова адчувалася б па-беларуску больш важка, не блякла, а надварот, набірала б сваю эпічную сілу (18).

Увогуле ж істотна, каб да перакладу звярталіся па вялікай творчай патрэбе, што натуральна садзейнічае пераадоленню ўмоўнасці знешняга падабенства, літаральнасці, а перакладчьк робічиа саауттарам, ён смель дзеля ўнутранай, вышэйшай дакладнасиі (25). Вырашальным у справе перакладу бачыцца А. Яскевічу вызначэнне глыбіннага тону арыгінала, дакладнае ўзнаўленне інтанацыі. Урэшце зыходным перакладчыцкім прынцыпам ён называе выяўленне цэнтральнага настрою твора, сцвярджаючы пры тым, што, вядома, далёкі ад думкі, каб ім і толькі ім вычарпачь увесь складань прачэс перастварэння. Безумойным патрабаваннем для перакладчыка з'яўляециа ўзнаўленне сюжэтнай асновы твора, усёи сістэмь яго вобразаў, каб яна паўстала ў пайнакройным пераўвасабленні новай мойнай рэальнасиі (68). Асобна разглядаюцца А. Яскевічам праблемы празаічнага перакладу, падкрэсліваецца, што пераклад прозы тоіць у сабе ці не больш невытлумачальных загадак, чым пераклад паэтычны...

Новых даследчыцкіх падыходаў у сферы перакладазнаўства запатрабаваў зварот літаратуразнаўца да "залатога" адраджэнскага беларускага веку, а менавіта даследаванне фенаменальнай дзейнасці Францьгка Скарыны па перакладзе $i$ вьцданні Бібліi ${ }^{10}$. У пра-

10 А. Яскевіч, Сумежжа: Мова, пераклад, вытокі прозы, Мінск 1994, с. 157. Далей пры спасылцы на гэта выданне ў дужках падаецца старонка. 
цы "Скарына - біблеіст і перакладчык" А. Яскевіч, на пачатку прааналізаваўшы стан скарыназнаўства па ўрачыстым юбілейным дзесяцігоддзі (1980-1990 гг.), звярнуй увагу на светапоглядныя прыярытэты вялікага асветніка, на ўпісанасць яго у пэӱную традыцыю, а менавіта у праваслаўна-славянскую. Была звернута ӱвага, што Прадмовы Ф. Скарыны і перакладзеныя ім тэксты сведчаць аб кананічнай строгасці ва ўзнаўленні біблейскіх ісцін. Даследчык цалкам усведамляў складанасць і адказнасць справы, здзейсненай першым беларускім перакладчыкам Святога Пісання:

Ф. Скарыне ж даводзілася вырашаць найскладанейшую задачу ўвасаблення неахопнага ў сваёй універсальнай касмічнай абстрагаванасці біблейскага тэксту, адшукваць яму эквіваленты сярод вусна-дыялектнай стыхіі народнай мовы, арыентаванай у сваім далітаратурным стане на абслугоўванне канкрэтна-побытавых патрэб жыцця і таму цяжка падатлівай да развіцця адцягненых значэнняў у слове.

Пераклад біблейскага тэксту - гэта вялікае выпрабаванне нацыянальнай мовы нават у самым сталым яе літаратурна-кніжным стане. Тым большая гэта была цаліна ў скарынінскі перыяд, калі літаратурныя нормы мовы толькі яшчэ пачыналі выпрацоўвацца. Пераклад у гэты перыяд літаральна абуджае мову з яе самаснага стану, ідзе плынь запазычанняў, па-новаму абшукваюцца свае лексічныя засекі (177-178).

Аналіз скарынінскага перакладу даваў падставы А. Яскевічу для высноў аб пэўных яго лексічных, сінтаксічных заканамернасцях. Так, пры перастварэнні кніг з высокім абагулена-эпічным гучаннем зместу вялікі палачанін трымаецца ўрачыстага ладу царкойнаславянскага тэксту. Перастварэнне адбываецца коштам замены малазразумелых царкойнаславянізмаў на агульнаўжывальную славянскую лексіку, якая ў першай палове XVI стагоддзя яшчэ была арганічнай для беларускай мовы. У сваю чаргу $\ddot{\mathrm{y}}$ кнігах з побытава-канкрэтным зместам назіраецца куды шырэйшае узжыванне непасрэдна беларускай лексікі...

Відаць, у значнай ступені асэнсаванне спадчыны вялікага беларускага асветніка вывела А. Яскевіча да засяроджання менавіта на біблейскіх перакладах. Вопыт жа даследавання перакладаў Ф. Скарыны ўпэўніў у тым, што пры перастварэнні біблейскага тэксту абсалютна непрыдатныя ні літаральная, ні творчая канцэпцыі, што якраз найлепш распрацаваны сучасным перакладазнаўствам. На думку А. Яскевіча: Перакладчык Бібліі перш за ўсё павінен быць усебакова падрыхтаваным тлумачальнікам, бо без багаслоусккай інтэрпрэтацыі тэксту у біблейскім перакладзе не прасунешся ні на крок(191). У пра- 
цы "Біблейскі пераклад"11 аўтар "Каранёў маладога дрэва" выяўляў сваю тэалагічную дасведчанасць, філалагічную, духойную падрыхтаванасць да шматпланавага аналізу перакладаў Кнігі Кніг.

Напрыканцы васьмідзесятых гадой пабачыла свет наватарскае даследаванне А. Яскевіча "Станаўленне беларускай мастацкай традыцыі", за якое у 1992 годзе даследчыку была прысуджана навуковая ступень доктара філалагічных навук. Ужо на самым пачатку сваёй манаграфіі А. Яскевіч удзячна адзначыў, што ажыццяўленне ягонага даследавання стала магчымым толькі на сучасным этапе, калі праведзены плённыя архіӱныя росшукі, з'явіліся фундаментальныя распрацойкі па гісторы беларускай літаратуры ${ }^{12}$. Увядзенне $\breve{y}$ навуковы ўжытак шэрагу матэрыялаў, крыніц давала магчымасць пераасэнсавання вядомых ужо фактай, сістэматызацыі, упісання ў агульны кантэкст паасобных працэсаў, аднак, зразумела, гэты новы крок не абяцаў быць лёгкім: Трудность состояла в том, что при почти полном отсутствии аналогов разработок в этом направлении в кругу доступных нам начиональньх школ литературоведения предстояло выполнить, по существу, комплексное исследование, т.е. показать формирование начиональной литературы как челостной художественной системь ${ }^{13}$.

Перарванасць беларускай кніжна-мойнай традыцыі, закладзенай яшчэ $\ddot{\mathrm{y}}$ скарынінскую эпоху, на жаль, аказалася вельмі ж балеснаю драмаю, калі не трагедыяй, на ўсю прышласць беларускага існавання. I вывучэнне наступствай і патрыятычнага, найчасцей самаахвярнага, імкнення, да пераадолення гэтай драмы пачалося пры разглядзе XIX стагоддзя генеральна толькі ̈̈ другой палове мінулага веку, ужо падчас сацыяльна-палітычнай адлігі, каб, трэба спадзявацца, здзейсніцца ўжо ва ўсёй цэласнасці. А. Яскевіч, якраз усведамляючы спецыфіку развіцця новай беларускай літаратуры, вырашаў

11 А. С. Яскевіч, Біблейскі пераклад. Зберажэнне тэксту, Мінск 1998. Гл. таксама: А. С. Яскевич, Вселенские тайнь человека, Минск 2012.

12 Гл.: А. І. Мальдзіс, Таямніць старажытных сховішчаў, Мінск 1974; В. А. Каваленка, Вьтокі. Уплььвы. Паскрпанасць. Равіциё беларускай літаратурь ХІХ-ХX стагоддзяў; Пачьнальнікі. 3 гісторька-літаратурных матэрылялаў ХIX cm. Укладальнік Г. В. Кісялёў, Мінск 1977; А. А. Лойка, Гісторыя беларускай літаратуры. Дакастрычнічкі перыяд. У 2 ч., Мінск 1977, ч. 1; А. І. Мальдзіс, На скрыжаванні славянскіх традыцыи. Літаратура Беларусі пераходнага перыяду (другая палова XVII-XVIII cmcm.), Мінск 1980 і інш.

13 А. С. Яскевич, Становление белорусской художественной традиции, Минск 1987, c. 5 . 
у сваім даследаванні шэраг асноватворных для айчыннага слова праблем, як напрыклад, пытанне нацыянальнай асновы ўзнікаючай літаратуры, разгляд мовы $\breve{y}$ аспекце яе пераходу $\ddot{y}$ літаратурна-кніжную форму, набыццё мовай усёй развітай сістэмы функцыянальна-стылявой дыферэнцыраванасці. На матэрыяле першых беларускіх паэм “Энеіда навыварат”, “Тарас на Парнасе”, творчасці Яна Чачота, Яна Баршчэўскага, Вінцэнта Дуніна-Марцінкевіча, Францішка Багушэвіча і шэрагу іншых аўтарай даследавалася зараджэнне пачатковых форм верша і прозы. Відавочна, шматгадовы вопыт літаратуразнаўцы і крытыка ўмацаваў А. Яскевіча ў перакананні лёсаноснай ролі народнай творчасці ў станаўленні літаратуранй традыцыі: вучоны кампетэнтна прасочваў шматаспектнасць фальклорнага ўплыву на розных этапах фарміравання новай беларускай літаратуры... Урэшце напрыканцы свайго даследавання з поўным правам аўтар манаграфіi “Станаўленне беларускай мастацкай традыцыі" сцвярджаў:

XIX век нашей литературы, развернувшейся перед нами величественной галереей писателей-подвижников, - это не только драма человеческих судеб, но и драма их культурного наследия. Из богатого творчества наших родоначальников сохранилось и вошло в литературный процесс немногое. Однако и его оказалось достаточно, чтобы зарождение белорусской литературы состоялось уже в прошлом веке, утвердилась многожанровая служба поэзии, возникла национальная драма, проза малых форм, развилась богатая публицистика, литературная критика ${ }^{14}$.

Варта падкрэсліць, што перыяд станаўлення новай беларускай літаратуры, падзвіжніцкае, будзіцельскае XIX стагоддзе нязменна працягвае заставацца $\ddot{\mathrm{y}}$ даследчыцкім полі зроку вынаходиа (...) новьл

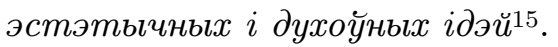

Выхад у свет новай манаграфіi А.Яскевіча "Рытмічная арганізацыя мастацкага тэксту" стаўся чарговым паглыбленнем даследчых пошукай, распачатых ім у першае дзесяцігоддзе працы у аддзеле тэорыі літаратуры акадэмічнага Інстытута літаратуры. У кнізе, якую склалі даследаванні трох аўтараў${ }^{16}$, А. Яскевічу належыў раздзел "Аспекты вобразнай структуры". Сярод іншага даследчык

14 Тамсама, с. 228.

15 Гл.. напр.: А. Яскевіч, В. Каратылскі: ля вылокаў нацыляальнай лірыкі $і$ эстэтыкі, "Полымя" 2008, № 5, с. 142-159.

16 В. П. Жураўлёў, І. С. Шпакойска, А. С. Яскевіч, Пытанні паэтыкі, Мінск 1974 , c. 224 . 
звяртаўся да моўнай рэальнасці вобраза, разглядай прадметна-малюнкавую аснову вобраза і ўрэшце засяроджваўся на рытме як кампаненце вобразнай структуры. У манаграфіі ж на аснове сучасных навуковых дадзеных (гіпотэзы дамоўнага стану думкі, рытмічныя законы мовы) прапаноўвалася ўдакладнёная мадэль рытмічнай структуры мастацкага тэксту. Ужо сама кампазіцыя кнігі з падзелам на сем раздзелаў ("Состояние теории", "Ритмообразующие факторы речи", "Основы прозаического ритма", "Мелодия прозы", "Переходные формы”, "Загадки силлабики", "Ритмическая организация силлабо-тоники"), у якіх паслядоўна рэалізавалася аўтарская задума, сігналізавала аб кампетэнтнасці працы. Істотна, што аўтар "Рытмічнай арганізацыі..." прапанойваў сваю методыку даследавання:

(...) от довербального состояния мысли, представленного интонацией, к раскрытию ритмическлй организации речи; затем на основе речевых законов - к изучению ритма прозы как более естественной ритмической формы. Такая последовательность позволяет оценить ритмическую систему стиха на фоне первично-естественных проявлений ритма в обыкновенной речи и прозаическом высказывании, дает возможность увидеть наращение ритмических уровней в стихе по сравнению с соответствующими уровнями исходного речевого ритма ${ }^{17}$.

Безумоўна, інтэрдысцыплінарны метад, шырока выкарыстаны ў манаграфіi А. Яскевіча, адкрываў новыя плённыя падыходы ў вывучэнні рытма прозы, рытмічнай пабудовы верша, а асэнсаванне гэтых праблем, відавочна, застаецца актуальным і ӱ новым міленіуме, тэхналагічныя магчымасці якога найчасцей уніфікуюць унутраныя творчыя працэсы.

На заканчэнне ўступнай i, зразумела, незавершанай характарыстыкі зробленага А. Яскевічам на ніве беларускмга літаратуразнаўства варта падкрэсліць, што пры заўсёдным імкненні вучонага дайсці да сутнасці даследуемых з'яў, глыбокай зацікаўленасці тэорыяй, даследчык ніколі не "здраджвае" непасрэднаму айчыннаму літаратурнаму працэсу. Сведчыць аб гэтым шэраг артыкулаў вучонага ў згаданай ужо чатырохтомнай акадэмічнай "Гісторы беларускай літаратуры XX стагоддзя", раздзелы ў калектыўных манаграфіях, салідныя часопісныя публікацыі.

17 А. С. Яскевич, Ритмическая организачия художественного текста, Минск 1991, c. 13-14. 
S T R E S Z C Z E N I E

\section{POSZUKIWANIA LITERATUROZNAWCZE ALESIA JASKIEWICZA}

W artykule omówiono wieloletnie badania literaturoznawcze profesora doktora habilitowanego Alesia Jaskiewicza (1934), należącego do tak zwanego pokolenia filologicznego - „lat 60-tych”, „dzieci wojny”. Podkreślono, że jego zainteresowania naukowe maja charakter wielowątkowy - od problemów kształtowania się nowej tradycji literackiej, psychologii twórczości, problemu stylu, struktury utworu, do kwestii przekładu i rytmicznej organizacji tekstu. Cechą charakterystyczną badań profesora jest szacunek zarówno do tradycji, jak i rozwiązań nowatorskich oraz zastosowanie metody interdyscyplinarnej.

Słowa kluczowe: tworzenie nowej tradycji artystycznej, twórczość narodowa, styl, przekład, psychologia twórczości, rytm, interdyscyplinarność.

\section{S U M M A R Y}

\section{ALES YASKYEVICH'S LITERATURE STUDIES}

In the article professor Ales Yaskyevich's (1934) literary studies are discussed. He belongs to the so-called philological generation - "sexagenerians", "children of war". The variety of his scientific interests such as creating new artistic tradition, psychology in writing, the problem of style, the structure of text, its rhythmic organization, translation is emphasized. A. Yaskyevich's studies respect both traditional and innovative approaches, they involve interdisciplinary method.

Although A. Yaskyevich is interested in theoretical and historical problems, he also remains committed to current literary process.

Key words: creating new artistic tradition, national creativity, style, translation, psychology in writing, rhythm, interdisciplinary. 